\title{
Spells, Spirits, and Charms in the Harlem Renaissance
}

\author{
Jamie Battaglia, Washington and Jefferson College
}

This article analyzes specific examples of magic found in two major artistic outlets of the Harlem Renaissance, jazz, and literature. Characters use voodoo and hoodoo to seek power and revenge, control the supposed stronger party, and give meaning to seemingly insignificant occurrences, thus offering a way for the artists of the Harlem Renaissance to control their own lives and black aesthetic achievement.

The Harlem Renaissance began in the early 1900s and created a new appreciation for the African-American race and heritage by fostering an emphasis on using history to educate the black population and create a sense of racial pride (Giggie 4). One example of using history to unite the African-American race was through voodoo or hoodoo, which derived from traditional African religion. In order to understand what voodoo and hoodoo was to the Harlem Renaissance, it is important to look at the history of the traditional Vodun beliefs and how the Great Migration brought magic to Harlem. Besides outlining the history of voodoo, hoodoo, and migration patterns, I will also be looking at specific examples of magic found in two major artistic outlets of the Harlem Renaissance, jazz and literature. I argue that through these pieces of art, it is evident that voodoo and hoodoo are both used to represent power by seeking revenge, controlling the supposed stronger party, and giving meaning to seemingly insignificant occurrences as a way for the artists of the Harlem Renaissance to control their own lives and artistic black movement.

Voodoo and hoodoo derive from the traditional African religion known as Vodun, which arrived in America with the settling of Jamestown in 1619 and with the slave trade (Mulira 112). The white settlers were scared of Vodun and did not understand the beliefs or practices; they would often try to suppress it. The forced suppression caused the blending of the traditional Vodun beliefs with other religions, such as Catholicism, creating an off-shoot of Vodun in the Caribbean and southern United States known as voodoo (Raboteau 115). Through the use of voodoo, one could pray to a specific deity with certain dances, offer a particular food or animal to the deity, or dress a specific way in order to receive protection (37). Another way to pray for help was by evoking spirits or ancestors, ultimately connecting Vodun worshippers with their past (36). Calling to ancestors proved to the Vodun believers that there were others "in charge" of their well-being besides those suppressing them, like slave masters. One way that the voodoo worshippers were in control over their own lives was through herb concoctions, like potions, that the herb doctor or Voodoo Queen would create as remedies for certain ailments (37).

The invoking of spirits, praying to someone or something other than the Christian God, 
the wild songs or dances, and the herbal concoctions seemed like dangerous magic to the white slave owners, something that was ultimately against their religion and way of life (Raboteau 37). To the voodoo worshippers, their religion was harmless and meant to be peaceful. However, there is a negative component to voodoo referred to as "hoodoo" ("Voudooism"). Although both traditions look for omens and meaning within ordinary life, hoodoo is harmful in nature, with curses, potions, and charms that are meant to cause physical or mental damage (Mulira 114). One aspect of hoodoo is the "fetish" ("Voudooism") that is made of cat or dog teeth, blood, feces of some sort, and is tied with a string. The fetish is left on the property of someone that one wishes to harm without the victim knowing. Another way a person can be cursed besides the fetish is through spirit hauntings, which in voodoo was seen as a good thing by making it apparent that ancestors or loved ones were watching over. However, with hoodoo, a spirit could be evoked to harm an individual or family (Mulira 114). To protect oneself from these spirits, a charm is needed to ward off evil, such as a rabbit's foot. The rabbit's foot and the fetish are two examples of gris-gris ("New Orleans"), which is defined as an object that wards off or stirs up magic. Another item considered to be gris-gris is the voodoo doll, typically used to inflict physical damage on someone without him or her knowing. In all, African Americans during slavery and early American history used hoodoo "to obtain revenge for their injuries, and to discover and punish their enemies" ("Voudooism").

Both voodoo and hoodoo are found in the Harlem Renaissance because of the Great Migration, which took place in the beginning of the twentieth century and until the 1970s in America (Gregory 12). During the Great Migration, eight million African Americans traveled from their southern homes and into major northern cities (14). The period of significant demographic change was considered to be "one of the greatest and most rapid internal movements of people in history" (15). The reason behind this "rapid internal movement" (15) was the lack of opportunity and equality for the African-American population in the South, especially with the passing of the Jim Crow laws, which permitted acts of segregation and hate. Besides the inequality the African Americans faced, there was little industry because people were still tied to land and agricultural production (23). For African Americans without land, there was no way to support a family. However, locations in the North such as Harlem were calling their names, and the same goes for African Americans from the Caribbean Islands like Barbados and Jamaica (23). With the migration northward to places like Harlem, African Americans brought their culture and traditional voodoo beliefs, songs, and dances with them (23). The influx of African culture in Harlem especially led to a new kind of "racial expression" (Giggie 132) in art, literature, song, and dance. Alain Locke in his essay "The New Negro," argues the importance of the new generation of African Americans, who were uniting in the artistic center of Harlem as well as creating and contributing to the intellectual progress of the race. He writes,

...more immediate hope rests in the revaluation by white and black alike of the Negro in terms of his artistic endowments and cultural contributions, past and prospective. It must be increasingly recognized that the Negro has already made very substantial contributions, not only in his folk-art, music especially, which has always found appreciation.... (15)

Locke is pointing out the African American appreciation for the past and present forms of art coming out of the Harlem Renaissance. He argues that the "racial expression" is evident 
in the folk-art and music and that there is a sense of hope found within the "New Negro" who uses his past to contribute to society, thus creating a new racial pride and autonomy. The emphasis on the black culture and race is what led to the Harlem Renaissance with the publishing of African-American artwork.

During the Harlem Renaissance, there was a new appreciation for the African roots and heritage, which can be seen in jazz and literature. Jazz was a major part of the Harlem Renaissance, and for some artists voodoo or hoodoo was influential to their pieces. Jelly Roll Morton, the "inventor of jazz" ("New Orleans"), credits voodoo as one of the main influences to his work. In fact, his godmother, Eulalie Hécaud was a famous Voodoo Queen in the South ("New Orleans"). One of the biggest stars during the Harlem Renaissance was Louis Armstrong, who grew up in New Orleans and roamed the streets of Storyville, which was a red-light district filled with cabarets, clubs, and shops ("New Orleans"). These shops were typically voodoo stores containing charms, potions, or fortune-tellers and were located next to the clubs or cabarets that Armstrong would sneak into (underage) in order to learn jazz ("New Orleans"). Another artist was Oscar "Papa" Celestin, who was a headliner during the early 1900s on Bourbon Street and openly credited voodoo as the inspiration to his work ("New Orleans"). Celestin crafted a song entitled "Marie Laveau," which was about the most famous Voodoo Queen in New Orleans ("New Orleans").

Voodoo served not only as the inspiration for jazz musicians but was also the subject of many jazz songs during the Harlem Renaissance. "Hoodoo Blues" by Bessie Brown, published in 1924, was about a woman who steals the singer's man and who wants to seek revenge through hoodoo curses (Brown). Bessie sings that she will: "sprinkle ding 'em dust all around her door" (Brown line 3) and "Burn a candle on her picture" (line 8). One way to curse someone with hoodoo was by taking his or her picture and burning a candle on the face of the photo, as well as spreading ashes or dust on the property of the victim, as Brown sings in the song (Mulira 114). Brown goes further and sings that she is "Goin' 'neath her window, gonna lay a black cat bone" (Brown line 6) and that she has "some gris-gris, tote it up in a sack" (line 8) that she's planning on wearing. Again, this ties back to the use of hoodoo objects known as gris-gris that evoke magic, like the sack that she wears to protect herself from curses or the bone that she places under the window of the victim to stir up harmful magic. It is interesting that Brown is singing about having power over another woman's well-being by inconspicuously placing hoodoo charms on the property of the victim. The woman initially had power over Brown by taking her man from her but, because of hoodoo, Brown has the power over the woman. The roles are reversed. The power struggle shown in "Hoodoo Blues" can be linked with the white race holding power over the African Americans with the Jim Crow laws and taking away something that they find important: equality and justice. When Brown sings about using hoodoo to seek revenge on the "other woman," she is in control over the one who wronged her, which is paralleled with the idea that the African Americans wanted to gain power and control over their own race without white interference or suppression.

Published four years after Bessie Brown's jazz song, Ma Rainey came out with her song titled "Black Dust Blues," which dealt with power being exercised over another person using hoodoo. The song is about a woman who is mad at Rainey because she feels like her man was stolen by her; it is quite similar to the concept of Brown's earlier song. In order to seek revenge, the woman places black dust around Ma Rainey's door. In line fifteen, Ma Rainey goes on to sing that the "black dust's got me walking on all fours like a cat." The woman was mad and wanted revenge for her man leaving her, so hoodoo was the only way 
for her to get the gratification she sought. For the victim of the curse, the only explanation for why she was walking like a cat was hoodoo. It seems as though hoodoo provides meaning and reason behind these unusual patterns or happenings within the context of the song. In this case, as readers or listeners, we see what hoodoo was like through the eyes of the singer who was the victim. It is evident that the person controlling her has the power and is able to do her harm. Ma Rainey is used as an example of the supposed stronger party-because she initially stole the woman's partner - being controlled through hoodoo by the weaker party.

Voodoo and hoodoo were important to the Harlem Renaissance because they tied in the traditional African beliefs with the idea of "racial expression" (Giggie 132). These songs are mainly about revenge and having the control to inflict harm, which is central to the practice of hoodoo. In some ways, there is an element of control that the believer of hoodoo has over another person. This power struggle can be linked with the idea that voodoo or hoodoo was something that could not be taken away by the white race; African Americans had control over it during the Harlem Renaissance. The writers and artists had the power to make the movement into anything that they wanted, and the Renaissance was something they could own and create. In times when they felt like they may not have had the artistic power to create anything they wanted, they yearned or aimed for it. They also looked to control their own race because society in the early 1900s was enforced by white leaders who worked to suppress the black race, which was evident with the Jim Crow laws. With cases of voodoo and hoodoo in jazz and literature, the weaker of the two parties were able to triumph over the more powerful using the spells, charms, or curses. The use of voodoo or hoodoo is a direct representation of the power that the African-American race yearned for; they wanted to triumph over the white race that worked to suppress them in society. Control and power were what the African Americans wanted, and magic served as the means to get that message across.

Jazz music contained copious references to voodoo and hoodoo, but it was not the only artistic outlet mentioning voodoo or hoodoo from the Harlem Renaissance. During this time of emphasis on black culture and artistry, many pieces of literature also included voodoo or hoodoo as subject matter. One reason behind the presence of magic in literature was because of immigration from the West Indies to the United States, namely Harlem. The Great Migration was not only made up of immigrants moving from the South to the North but also from out of the country and into it. For example, Albert Raboteau points out that during the Great Migration, "Immigrants from Puerto Rico, Cuba, and Haiti... introduced the traditional gods of Africa to the United States" (105). These immigrants helped to spread traditional voodoo and hoodoo beliefs and customs to the black and Hispanic families across the United States during the early 1900s (Raboteau 105). In Cuba and Haiti especially, the believers of voodoo and hoodoo would practice different rituals that involved singing, dancing, and drumming, which ultimately derived from Africa and the traditional Vodun beliefs (105). These rituals and celebrations of the gods came to America along with the idea that the spirits have control or power over the lives of others. By appeasing the gods, the voodoo worshippers would contract the favor of the gods and would then be healed or given luck (105). There was also a major belief in spirit possessions and the impact that the spirits had on the lives of people. During these spirit possessions, "entranced mediums made personal contact between gods and humans possible by embodying the god for the community" (105). If something may have gone wrong, the voodoo priests would look to the spirits as the cause and prescribe different methods to set things right (105). These voodoo beliefs from the West Indies came into the United States during the Harlem Renaissance, which can be seen with the famous writers who were from these same regions. Claude McKay 
grew up in Sunny Ville, Jamaica and was familiar with voodoo and hoodoo beliefs, which he brought with him to Harlem ("Claude McKay: 1889-1948”). The same goes for Eric Walrond, who was from Barbados and also wrote about voodoo and hoodoo (Honey and Patton 410). When these writers came to the United States, they brought their beliefs with them and incorporated the magic into their work. The same goes for Zora Neale Hurston, who did anthropological research on voodoo in Haiti and Jamaica, which led to many books and stories related to the voodoo she observed on the islands (322-323). Instead of leaving her research on the island, she brought it back to Harlem and shared it with the African American community. These writers incorporated voodoo and hoodoo culture into their work in order to display the power that the characters in their stories had over others as well as to show how the voodoo and hoodoo culture was something that was a part of them.

One such example is Home to Harlem by Claude McKay, which was published during the Harlem Renaissance. In the novel, Jake is suffering from a painful STD, and his landlady is watching over him periodically. At one point, Jake decides to go out to a restaurant without telling his landlady, who decides to look for him in his apartment (McKay 118). She went into the kitchen, stumbled, and broke a white bowl, then "made a sign with her rabbit foot, and murmured foggily: 'Theah's sure a cross coming to thisa house. I wonder it's foh who?" (118). Following the breaking of the bowl, the answer to her question is given, when Jake comes into the room supported by two men (118). First, the rabbit foot in this story represents an example of gris-gris or a protection charm that was important to both voodoo and hoodoo (Mulira 114). The breaking of the bowl is seen as some kind of omen, and because of this omen the landlady was able to determine that someone in the house was sick or seriously ill. She is attaching meaning to an insignificant event (the breaking of the bowl) as well as bringing luck and protection to herself by giving meaning to the rabbit's foot. With the foot in her possession, she can control her own luck and create a power in knowing (through voodoo and hoodoo) that something has gone awry.

The idea of power and control is apparent through other works such as Zora Neale Hurston's "Spunk." Hurston was very interested in voodoo in the Caribbean and included it in both stories and novels such as Their Eyes Were Watching God and Tell My Horse (Honey and Patton 322-323). "Spunk" is told through the eyes of the townspeople, who gossip about the love triangle between Joe, Spunk, and Lena. Spunk has taken Joe's wife, Lena, and they walk arm in arm throughout the town. Joe finally is fed up with their affair, so he goes with a razor to kill Spunk, who is a large and fierce man (Hurston 326). Spunk ends up killing Joe and moving in with Lena. However, Joe comes back as a spirit and haunts both Spunk and Lena as a black bobcat. One of the gossiping men, Elijah, was reporting to Walter about the bobcat when he says, "jus' as they was goin' to bed, a big black bobcat, black all over, you hear me, black, walked round and round that house and howled" (328), and when Spunk went to shoot it, the bobcat just stared in his eyes. Elijah went on, "But Spunk says twan't no bob-cat nohow. He says it was Joe done sneaked back from Hell!" (328). The gossiping men believe it was the spirit of Joe because there are no black bobcats in that area and it was highly symbolic that the bobcat stared at Spunk. The appearance of the black bobcat shows how spirits could come back and harm the living, cursing Spunk because he stole Joe's wife. The story makes it seem as though some kind of magic or spiritualism is involved to seek revenge. Spunk's luck did not get any better when he felt as though he was continuously being pushed, yet no one was behind him. Finally, he was pushed to his death, and his last words were, "[H]e pushed me,'Ligeo the dirty hound pushed me in the back" (329). Spunk's final death is similar to how Joe anticipated killing 
Spunk in the first place, by sneaking up on him from behind with a razor. This relates to voodoo and hoodoo because it shows how the spirits could be present on Earth, meddling with living humans.

Spiritualism was a major belief within the traditional Vodun religion and the belief in spirits was evident with Joe coming back to earth to haunt Spunk (Mulira 115). In terms of voodoo, there is no other reason as to why Spunk fell; his death was blamed on a spirit, nothing else. This points to the idea of magic providing an explanation for unusual occurrences. Joe had the power over Spunk in the end because he was able to seek revenge on the man that took his wife. The story also suggests that a weaker person (like Joe) can ultimately have power over someone who is perceived to have more control (Spunk). The power struggle between the characters in "Spunk" is comparable to the Harlem Renaissance because the African-American artists wanted control over their own movement and conditions in life. They did not feel as though the white race had any right to hold power over them, and, by showing the weaker overcoming the more powerful, Hurston is giving hope to the African-American race. She is using voodoo and hoodoo to show the representation of the black race (the weaker) holding power over the white race (more powerful). In the case of "Spunk," voodoo or hoodoo represents spiritualism, power, revenge, and the idea that magic can explain unusual events.

These same ideals can be found in another story by Hurston called "Black Death." The main character was an "excessively black hoodoo man" (Hurston) named Old Man Morgan who was well-known by everybody (except for the white people) because he could "kill any person indicated and paid for, without ever leaving his house or even seeing his victim" (Hurston). For example, Morgan "caused Emma Taylor's teeth to drop out," he "put a sprig of Lena Merchant's hair in a bottle, corked it and threw it into a running stream with the neck pointing upstream, and she went crazy," and "sent Old Lady Crooms [his voodoo rival] to her death in the Lake" (Hurston). Morgan would make concoctions or charms from the woods where he would dig for different roots and herbs (Hurston). The story "Black Death" displays the important aspects of hoodoo culture, including herbal medicine, potions, charms, and curses. Old Man Morgan was able to exert power or exact revenge over others by doing them physical harm. For example, in the text, a man named Beau got a woman pregnant. Unfortunately, Beau refused to marry her and left her with her mother. In order to seek revenge on Beau, Mrs. Boger (the mother of the pregnant woman) awoke in the middle of the night with "all Africa" in her blood, "tribal drums beating," and walked over to Morgan's cabin (Hurston). Before she knew what she was doing, Morgan gave her a gun and put the image of Beau onto a mirror. Mrs. Boger shot the gun, killing Beau in the mirror and in reality. His death was pronounced "natural" because it stemmed from a supposed heart attack (Hurston). Hurston's last remark in the story was that the white people still had no idea and would not believe this story, but the African Americans knew Morgan was behind Beau's death. Hurston's story connects Africa with hoodoo and hoodoo with the Harlem Renaissance, showing the power that the hoodoo men had over others by seeking revenge. Hoodoo was a source of culture that gave the African Americans some sort of autonomy; whites didn't understand it in the way that they did, and no matter what injustices the white race did to the African Americans, they could not take voodoo or hoodoo away from them. The use of magic goes along with the idea of the power struggle as well because Beau had power over the Boger women by declaring that he wanted nothing to do with the woman he impregnated. Beau left her helpless, and one way that the two hurt women sought revenge or power over Beau was through the use of hoodoo. The story represents the 
idea of the weak gaining power over the supposedly strong, and the use of hoodoo ties to the African Americans in the Harlem Renaissance wanting control over their own lives and conditions despite their supposed minority race status or weaker position in society.

The power struggle between strong and weak is found in Eric Walrond's "The Voodoo's Revenge." Published in 1925 in a popular magazine during the Renaissance, Opportunity, the short story was influenced by his childhood in Barbados (410). The story is about Nestor Villaine who lives as an "obeah man" (Walrond 412), which was a sacred person who knew and practiced voodoo or hoodoo. It takes place on a Caribbean island where shipping was prominent as well as men who sang "voodoo melodies" (411). Nestor was unjustly thrown in prison for 60 days, and when he got out, he wanted revenge on the man who put him in jail and caused him the most trouble. He finds a waiter named Sambola, who was a young male server at the Chess Club meetings his victim attended. Nestor made Sambola drink a potion out of a vial but also gave him a second vial that contained an odorless and colorless concoction to slip into Governor Manual Salzedo's drink (418). When Sambola snuck the vial into the governor's drink undetected, Salzedo promptly died, shocking the people of the island. In fact, "not even the enterprising reporters of the fictional press [knew what happened] — not one of them ever thought of linking the governor's death with the finding a few days later of a Negro's shark bitten body fished up out of the black lagoon on Faulke's River" (418). It makes the reader come to the conclusion that voodoo or hoodoo occurred and that the narrator knows something that the reader does not. Sambola continued to serve drinks at the Chess Club meetings but,

Only sometimes, a strange, smoky gleam would creep into his eyes. On nights when he'd go to that brothel on the banks of the river...there were those who couldn't help compare it with the cat-like light they had often seen in the eyes of the old grouchy trader, Nestor Villiane. As a matter of fact, folk oftimes, for no reason they could explain, referred to Sambola as Nestor Villiane. (418)

The ending of the story points to some kind of body-switching or magic that may have taken place. Because Nestor was a voodoo man, it is apparent that the vials he gave out were likely potions, and hoodoo was done to seek revenge on the governor. Nestor may not have had control over his own life when he was in jail, but once he got out, he took revenge and held power over the governor. "The Voodoo's Revenge" represents the power struggle between the weak and the strong.

In terms of a racial struggle, Nestor Villiane represents the African-American race that is being suppressed by the governor, who holds the most political power, much like the white race in the 1900s. The way in which Villiane took control was through the use of hoodoo, which allowed him power over the governor. Voodoo or hoodoo is linked with the weak having power over the supposed stronger, like the African Americans yearning for power over their suppressors, the white race. Through these artistic outlets of the Harlem Renaissance, it is evident that power is what drove the references to magic. Voodoo or hoodoo was used as a means to seek revenge, explain unusual occurrences, and most importantly, represent the suppressed African-American race in the struggle for power. Racial pride and power fits in with the idea of the New Negro, a term used to describe the educated, socially aware, and independent African American. The New Negro respects his past but looks to the future. Voodoo and hoodoo served as that outlet by allowing the black race to embrace 
their traditional African roots while also looking to empower the race and triumph over suppressors. Hoodoo and voodoo were important to the Harlem Renaissance and the New Negro because it served as a way for African Americans to look at their past while also embracing the power and control they sought for the future.

The Harlem Renaissance served as a time of artistic growth for the members of the black community. African-American people from the South came to Harlem in large numbers for many different reasons, including injustice and lack of opportunity. The period of the Great Migration added culture to Harlem through songs, dance, rituals, and religion. Two types of art that took off within the Harlem Renaissance were jazz and literature, both containing references to Vodun, or voodoo and hoodoo. The common denominator found in the jazz and literature pieces is voodoo and hoodoo as a representation of attempting to control one's own life, which meant seeking revenge on others, providing an explanation for coincidental occurrences, and, most importantly, representing the idea that the minority race wanted power over their own lives. Artists from the Harlem Renaissance looked to voodoo or hoodoo in order to give their characters that same control or power over events or their lives within the stories or songs that they yearned for in the early 1900s. These artists wanted to show the population, white, black, or even any race, that, like the characters that had control in the stories, power could be found in the minority. These stories and songs serve as a representation of the want, need, or acquisition of power during the Harlem Renaissance. 


\section{Works Cited}

Brown, Bessie. "Hoodoo Blues." Ed. Catherine Yronwode. Blues Lyrics and Hoodoo: Supplementary Transcriptions from Hoodoo in Theory and Practice. 1995. Web. 9 Nov. 2013.

“Claude McKay: 1889-1948.” The Poetry Foundation. 2013. Web. 12 Nov. 2013.

Giggie, John M. After Redemption: Jim Crow and the Transformation of African American Religion in the Delta, 1875-1915. New York: Oxford University Press, 2008. Print.

Gregory, James N. The Southern Diaspora: How the Great Migration of Black and White Southerners Transformed America. Chapel Hill: University of North Carolina Press, 2005. Print.

Honey, Maureen, and Venetria K. Patton. "Eric Walrond." Double-Take: A Revisionist Harlem Renaissance Anthology. Ed. Maureen Honey and Venetria K. Patton. New Brunswick, New Jersey: Rutgers University Press, 2001. 410-411. Print.

---. “Zora Neale Hurston.” Double-Take: A Revisionist Harlem Renaissance Anthology. Ed. Maureen Honey and Venetria K. Patton. New Brunswick, New Jersey: Rutgers University Press, 2001. 322-323. Print.

Hurston, Zora Neale. “Black Death.” 1925. 9ALPS. Ed. J.E. Thurnau, 2011. PDF file. Web.

---. "Spunk." Double-Take: A Revisionist Harlem Renaissance Anthology. Ed. Maureen Honey and Venetria K. Patton. New Brunswick, New Jersey: Rutgers University Press, 2001. 325-338. Print.

Locke, Alain. "The New Negro." 1925. The New Negro. New York: Simon \& Schuster, 1992. 3-16. Print.

McKay, Claude. Home to Harlem. 1928. Boston: Northeastern University Press, 1987. Nook version.

Mulira, Jessie G. "The Case of Voodoo in New Orleans." Africanisms in American Culture. 2nd ed. Ed. Joseph E. Holloway. Bloomington: Indiana University Press, 2005. 111-151. Print.

The New Orleans Historic Voodoo Museum. The New Orleans Historic Voodoo Museum. 2009. Web. 12 Nov. 2013.

Raboteau, Albert J. A Fire in the Bones: Reflections on African-American Religious History. Boston: Beacon Press, 1995. Print. 


\section{Works Cited}

Rainey, Ma. "Black Dust Blues." Ed. Catherine Yronwode. Blues Lyrics and Hoodoo: Supplementary Transcriptions from Hoodoo in Theory and Practice. 1995. Web. 9 Nov. 2013.

"Voudooism: African Fetish Worship among the Memphis Negroes." Weekly Georgia Telegraph. 13 Nov. 1868: E. InfoTrac. Web. 12 Nov. 2013.

Walrond, Eric. “The Voodoo's Revenge." Double-Take: A Revisionist Harlem Renaissance Anthology. Ed. Venetria K. Patton and Maureen Honey. New Brunswick, NJ: Rutgers UP, 2001. 411-418. Print. 